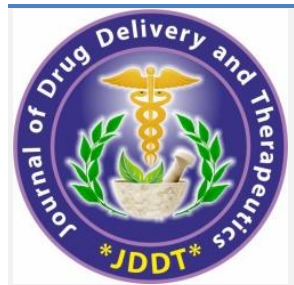

Open Access Full Text Article

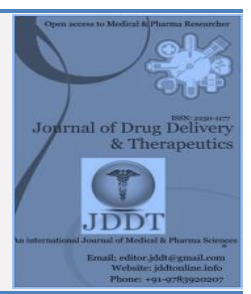

\title{
Method Development and Validation of Polmacoxib in Capsule Dosage Form by RP-HPLC
}

\author{
Anjali Chaudhary ${ }^{1}$, Meenakshi Dhaiya ${ }^{1}$, Shaily Tyagi ${ }^{1}$, (DSwati Mittal2* \\ 1. Indian Pharmacopoeial Commissions, Ministry of health and family welfare, Government of India, Sector-23 Rajnagar, Ghaziabad-201002. \\ 2. HIMT College of Pharmacy, Department of Pharmaceutics, Knowledge park1, Gr. Noida (U.P), India
}

\section{Article Info:}

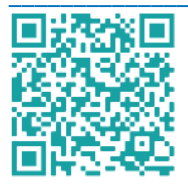

\section{Article History:}

Received 06 June 2021

Reviewed 11 July 2021

Accepted 19 July 2021

Published 15 August 2021

\section{Cite this article as:}

Chaudhary A, Dhaiya M, Tyagi S, Mittal S, Method Development and Validation of Polmacoxib in Capsule Dosage Form by RP-HPLC, Journal of Drug Delivery and Therapeutics. 2021; 11(4-S):59-63

DOI: http://dx.doi.org/10.22270/jddt.v11i4-S.4984

\section{Abstract}

A simple and sensitive RP-HPLC method developed for estimation of Polmacoxib in bulk by using a high performance liquid chromatography with PDA detector using Phenomenex luna C18 column (250 mmx4.6mm), $5 \mu \mathrm{m}$; mobile phase comprises of Water : ACN as (1:1) at the flow rate $1.0 \mathrm{ml} / \mathrm{min}$ and the wavelength of detection $238 \mathrm{~nm}$ and eluted at 8.12 minutes. The proposed method is validated for specificity, Linearity, Precision, accuracy, ruggedness, and Robustness. All the parameters were found within the acceptable limits. RP-HPLC method was a simple, reliable economic and acceptable and it confirmed that method is suitable for the intended use for routine quality control and assay of drugs. This method is successfully applied for the determination of commercial dosage form capsule preparation. This method is validated as per ICH (International conference on harmonization) Guidelines.

Keywords: Polmacoxib, RP-HPLC, ICH, PDA Detector, Precision

*Address for Correspondence:

Swati Mittal, HIMT College of Pharmacy, Department of Pharmaceutics, Knowledge park1, Gr. Noida (U.P), India ORCID ID: https://orcid.org/0000-0002-9829-9068

\section{INTRODUCTION:}

Polmacoxib is 4-[3-(3-fluorophenyl)-4,5-dihydro-5,5dimethyl-4-oxo-2-furanyl]-benzenesulfonamide. Its molecular formula is $\mathrm{C}_{18} \mathrm{H}_{16} \mathrm{FNO}_{4} \mathrm{~S}$ and molecular weight is $361.39 \mathrm{gm} / \mathrm{mol}$.

\section{Structure}<smiles>CC1(C)OC(c2ccc(S(N)(=O)=O)cc2)=C(c2cccc(F)c2)C1=O</smiles>

Polmacoxib, developed as CG100649 is also a selective cyclooxygenase-2 (COX-2) inhibitor, a type of non-steroidal antiinflammatory drug and acts as a potent inhibitor of several other CA isoforms (CA I and II), due to its aryl sulfonamide moiety, similar to

celecoxib and valdecoxib. ${ }^{1}$ Unlike other NSAIDs, polmacoxib has a dual mode of action: inhibition of COX-2 and binding to carbonic anhydrase (CA) with high affinity. A key function of $\mathrm{CA}$ is to regulate the $\mathrm{pH}$ level in the body through the interconversion between carbon dioxide and bicarbonate. Where COX-2 and CA coexist, the high-affinity binding of polmacoxib to CA reduces the COX-2 inhibitory activity of polmacoxib. Preliminary experiments have shown the COX-2 inhibitory activities of polmacoxib with varying amounts of CA in the system. ${ }^{2}$ Lower intestine perforation caused by selective COX-2 inhibitors has been reported, but its incidence is extremely low. ${ }^{3}$ CG100649 in water is very low, and the different lattice energies of polymorphs give rise to different solubilities and dissolution rates. It is also Soluble in Acetone, DMSO, and DMF (Dimethyl formamide). 4 Reversed phase chromatography has found both analytical and preparative application in the area of biochemical separation and purification. Molecules that possess some degree of hydrophobic character can be separated by reversed phase chromatography with excellent recovery and resolution. 5 The separation mechanism in reversed phase chromatography depends on the hydrophobic binding interaction between the solute molecule in the mobile phase and the immobilised hydrophobic ligand, i.e. the stationary phase. The actual nature of the hydrophobic binding interaction itself is a matter of heated debate but the conventional wisdom assumes the binding interaction to be the result of a favourable entropy effect. The initial mobile phase binding conditions used in reversed phase chromatography are primarily aqueous which indicates a high degree of organised water structure surrounding both the solute molecule and the immobilised ligand. As solute binds to the immobilised hydrophobic ligand, the hydrophobic area exposed to the solvent is minimised. 
Therefore, the degree of organised water structure is diminished with a corresponding favourable increase in system entropy.

In this way, it is advantageous from an energy point of view for the hydrophobic moieties, i.e. solute and ligand, to associate. 6

\section{MATERIAL AND METHODS}

\section{Instrumentation and Equipment}

In this experiment Waters Alliance2695 Separation Module integrated with Waters 2996 Photodiode Array Detector at 238nm using Phenomenex Luna C18, column (250mmx4.6mm), $5 \mu \mathrm{m}$ was used and data was integrated using a Empower Pro software.

All the weighing in the experiments was done with Mettler Toledo analytical balance capable of measuring with an accuracy of $0.1 \mathrm{mg}$. The solubility was enhanced by sonication on an Ultrasonic bath.

Glass wares used in the entire process were thoroughly cleaned and calibrated.

\section{Reagents and Chemicals}

ACN (Thermo Fischer scientific) \& Water (HPLC Grade)

Reference standard and Test Samples

Reference Standard and test samples of Polmacoxib were arranged from Indian Pharmacopoeia Commission (IPC) Ghaziabad.

\section{Methods}

\begin{tabular}{|l|l|}
\hline Chromatographic Condition \\
\hline Column & $\begin{array}{l}\text { Phenomenex Luna C18, column } \\
(250 \mathrm{~mm} \times 4.6 \mathrm{~mm}), 5 \mu \mathrm{m}\end{array}$ \\
\hline Organic Phase & ACN: Water $(60: 40)$ \\
\hline Detector & PDA detector \\
\hline Flow Rate & $1.0 \mathrm{~mL} / \mathrm{min}$ \\
\hline Wavelength & $238 \mathrm{~nm}$ \\
\hline Injection Volume & $20 \mu \mathrm{L}$ \\
\hline Temperature & Ambient \\
\hline Diluent & Water and ACN in ratio $50: 50 \mathrm{v} / \mathrm{v}$ \\
\hline
\end{tabular}

\section{Preparation of Standard stock Solution}

50.78mg of Polmacoxib RS was weighed and transfer into $50 \mathrm{ml}$ volumetric flask then added small volume of diluent and sonicate for 5 minutes to dissolve and dilute up to the mark with diluent.

\section{Preparation of Standard Solution}

Further pipette $10 \mathrm{ml}$ from the standard stock solution into $100 \mathrm{ml}$ volumetric flask and then dilute up to mark with diluent which possess the concentration of Polmacoxib RS $100 \mu \mathrm{g} / \mathrm{ml}$.

\section{Preparation of Sample solution}

$51.18 \mathrm{mg}$ of Polmacoxib was weighed accurately and transfer into $50 \mathrm{ml}$ volumetric flask then added small volume of diluent and sonicate to dissolved for 5-10 minutes and dilute up to the mark with diluent. Further pipette $10 \mathrm{ml}$ from this solution into $100 \mathrm{ml}$ volumetric flask and then dilute up to the mark with diluent.

The prepared solutions were stored at room temperature which possesses the concentration of $100 \mu \mathrm{g} / \mathrm{ml}$.

\section{Method Validation}

The developed method was validated with respect to system suitability, specificity, linearity, precision, accuracy LOD, LOQ and robustness in the accordance of the ICH Q2 guidelines.

\section{Specificity and selectivity}

The developed method was found to be selective for Polmacoxib, since the injection of the blank solution confirmed the absence of interfering peak at RT examined substance at $238 \mathrm{~nm}$. The results obtained demonstrate that there was no interference from other material in the developed method and therefore confirm the specificity of the method.

\section{System Suitability}

System Suitability tests are an integral part of method development and were used to ensure adequate performance of the chromatographic system. Retention Time (RT), tailing factor, peak asymmetry, and theoretical plates (T) were evaluated. The results are shown here in Table 1.

Table 1: System suitability parameters of Polmacoxib

\begin{tabular}{|l|l|l|l|}
\hline Sr. No. & Property & Polmacoxib & Acceptance criteria \\
\hline 1. & Retention Time (RT) & 8.12 & - \\
\hline 2. & Tailing factor (T) & 1.01 & NMT 2.0 \\
\hline 3. & Theoretical plates (N) & 16336 & NLT 2000 \\
\hline
\end{tabular}

From the data it was found that all the system suitability parameters for developed method were within the limit.

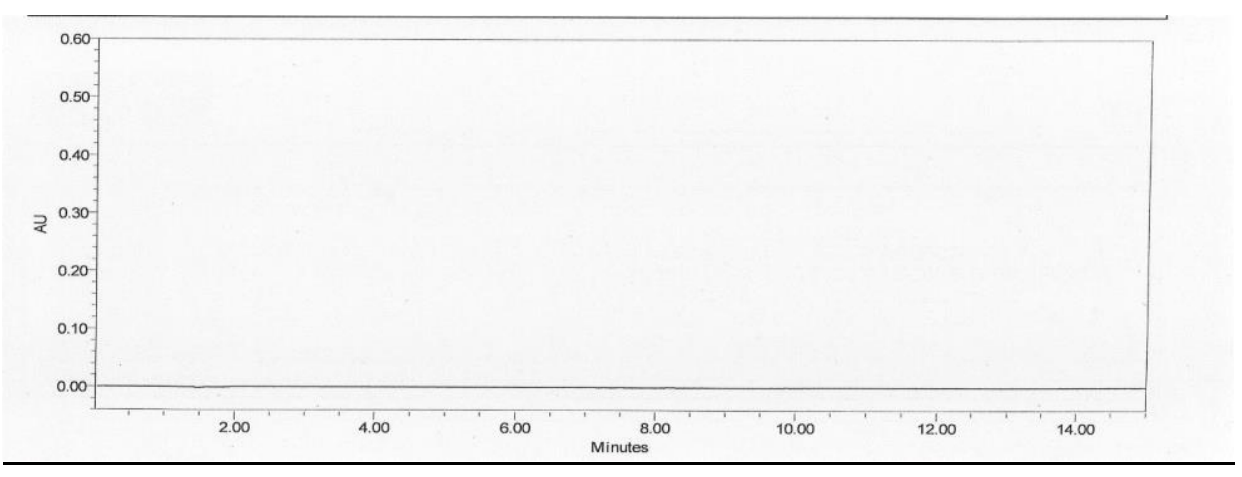

Chromatogram: Blank of Polmacoxib 


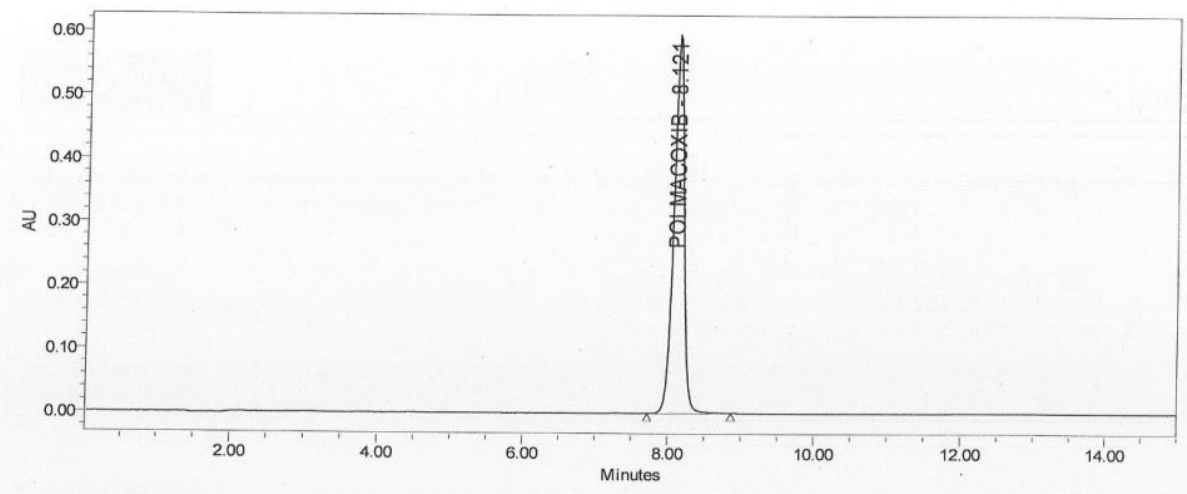

Chromatogram: Standard of Polmacoxib

\section{Linearity and Range}

Linearity of the developed method demonstrates the ability of method to produce a result which is directly proportional to concentration of analyte in the sample. The amount of Polmacoxib was prepared for linearity in the range of 80 -
$120 \mathrm{ppm}$.The amount of polmacoxib in five different concentrations is $80 \mathrm{ppm}, 90 \mathrm{ppm}, 100 \mathrm{ppm}, 110 \mathrm{ppm}$ and $120 \mathrm{ppm}$ respectively. The graph was plotted between concentrations versus area of peak. The Polmacoxib shows good correlation coefficient $\left(\mathrm{r}^{2}=0.999\right)$ and the proposed method was linear in concentration range 80-120 ppm.

Table 2: Linearity of Polmacoxib

\begin{tabular}{|c|c|c|c|c|c|c|c|c|}
\hline S. No. & Compound & & & lues of X & Y variab & & & Correlation \\
\hline \multirow{3}{*}{1.} & \multirow{3}{*}{ Polmicoxib } & Variable & 1 & 2 & 3 & 4 & 5 & \multirow{3}{*}{0.999} \\
\hline & & $\mathrm{X}$ & 80 & 90 & 100 & 110 & 120 & \\
\hline & & $\mathrm{Y}$ & 4737372 & 5276776 & 5887575 & 6470577 & 7033314 & \\
\hline
\end{tabular}

Note: $\mathrm{X}$ is the concentration of the respective component in $\mu \mathrm{g} / \mathrm{ml} . \quad \mathrm{Y}$ is the peak response of the respective component in area counts.

\section{Linearity Curve}

Calibration curve was constructed between concentrations versus peak area. Results were recorded for equation of line,

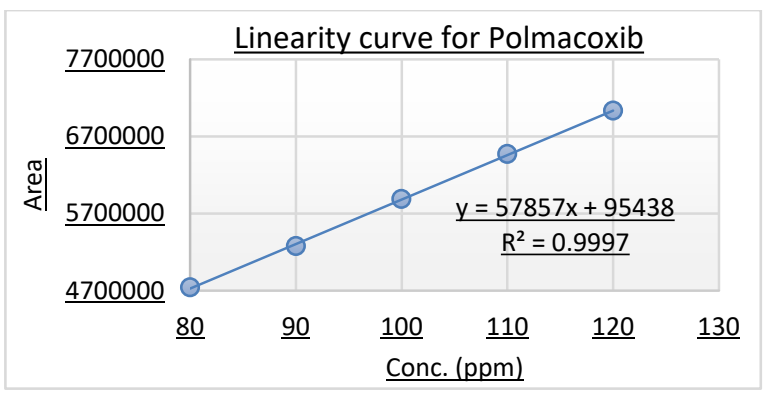

\section{Precision}

It reveals the data regarding closeness between the series of measurements. The precision of the developed method was verified by system precision and method precision. A homogenous sample $100 \mu \mathrm{g} / \mathrm{mL}$ of Polmacoxib was prepared correlation coefficient and intercept were determined. Where, Y- area X- Unknown concentration m- Slope of graph c- Intercept.

\begin{tabular}{|l|l|}
\hline Concentration $(\mu \mathrm{g} / \mathrm{ml})$ & Area count \\
\hline 80.0 & 4737372 \\
\hline 90.0 & 5276776 \\
\hline 100.0 & 5887575 \\
\hline 110.0 & 6470577 \\
\hline 120.0 & 7033314 \\
\hline
\end{tabular}

under prescribed conditions and estimation was carried out The results are expressed in the form of standard deviation and RSD value. Table 2 shows the result of system precision and method precision respectively and the developed method is highly precise as \% RSD is less than $2 \%$.

Table 3:_Calculation of \%RSD for Polmacoxib (System Precision)

\begin{tabular}{|c|c|c|c|c|c|c|c|c|c|c|}
\hline S. & Compound & \multicolumn{6}{|c|}{ No. of Injections } & - & & \\
\hline \multirow[t]{2}{*}{1.0} & Reference & 1 & 2 & 3 & 4 & 5 & 6 & \multirow[b]{2}{*}{5843765} & \multirow[b]{2}{*}{11641.9} & \multirow[b]{2}{*}{0.19} \\
\hline & (RS) & 5834761 & 5841957 & 5842318 & 5840198 & 5836622 & 5866732 & & & \\
\hline
\end{tabular}


Table 4: Calculation of \%RSD for Polmacoxib (Method Precision)

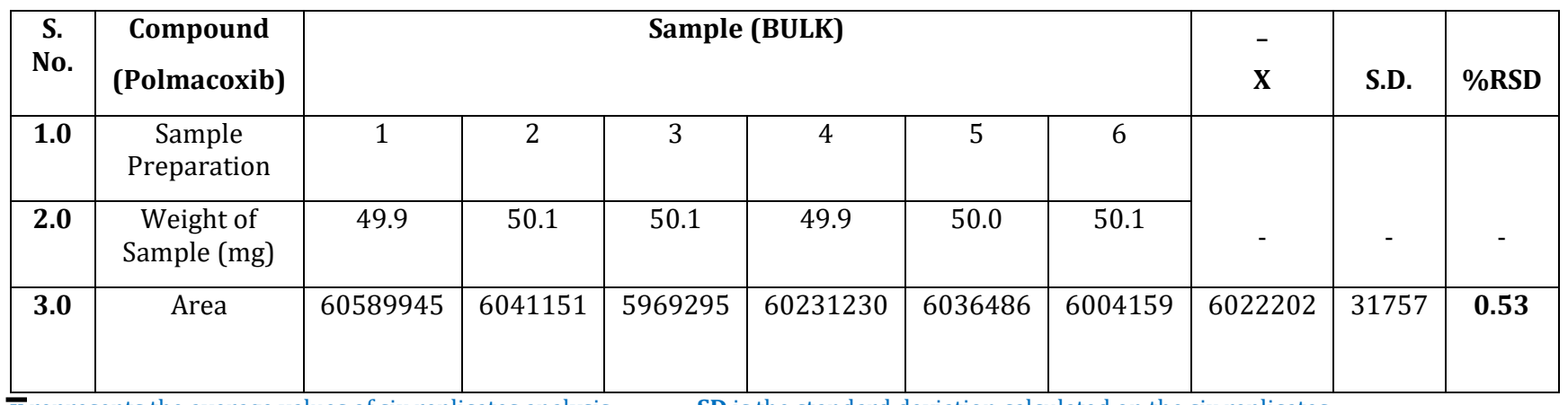

$\overline{\mathbf{x}}$ represents the average values of six replicates analysis.

$\mathrm{COV}$ is the coefficient of variation.

SD is the standard deviation calculated on the six replicates.

Table 5: System Precision and Method precision

\begin{tabular}{|l|l|l|}
\hline Precision & Drug & \% RSD \\
\hline System precision & Polmacoxib & 0.19 \\
\hline Method precision & Polmacoxib & 0.53 \\
\hline
\end{tabular}

\section{Accuracy}

It is also termed as trueness or recovery. This method was determined using $80 \%, 100 \%$ and $120 \%$ of working strength of Polmacoxib. Each level solution was prepared in triplicate and analysed as per the method given. This is usually demonstrated in the form of SD and RSD. The results reveal that the value of \% RSD is less than $2 \%$. The percent recovery results are in Table: 6.0

Table 6: Summary of assay of Polmacoxib

\begin{tabular}{|c|c|c|c|}
\hline S. No. & Level & $\begin{array}{c}\text { \% Average Assay } \\
\text { (ODB) }\end{array}$ & \%RSD \\
\hline 1 & $80 \%$ & 100.39 & 0.08 \\
\hline 2 & $100 \%$ & 99.97 & 0.27 \\
\hline 3 & $120 \%$ & 99.89 & 0.29 \\
\hline
\end{tabular}

The percentage of assay value of polmacoxib in the range of 99.22-100.0 \% and the \% RSD of assay value obtained was in the range of $0.08-0.37 \%$. The study proves that the method is accurate for the estimation of Polmacoxib assay over the range of $80-120 \%$ of target concentration

\section{LOD and LOQ (Limit of Detection and Limit of Quantification)}

Limit of detection (LOD) and Limit of Quantification (LOQ) reveal information regarding concentration of analyte that yields signal-to-noise around 1 to 10 . Serial dilutions are made from solution of Polmacoxib for determination of LOQ and LOD. The samples were injected in HPLC and compare the signals of sample and blank sample of LOD and LOQ. According to earlier mentioned parameters, LOD and LOQ were estimated for Polmacoxib0.5 $\mu \mathrm{g} / \mathrm{ml}$ and $1.5 \mu \mathrm{g} / \mathrm{ml}$.

Table 7: LOD \& LOQ studies of Polmacoxib

\begin{tabular}{|l|l|l|}
\hline Drug & LOD & LOQ \\
\hline Polmacoxib & $0.5 \mathrm{ppm}$ & $1.5 \mathrm{ppm}$ \\
\hline
\end{tabular}

\section{Robustness}

The robustness of the developed HPLC method was carried out by making small deliberate changes in the HPLC process parameters. These parameters include variation in wavelength, flow rate of mobile phase and changes in proportion of buffer and ACN. The method was performed on single concentration of sample of Polmacoxib. (--) The alteration of parameters may leads to some significant changes in the peak area and RSD. Robustness studies concludes that the method is robust under \pm 2 wavelength, \pm $10 \%$ flow rate and $\pm 10 \%$ increase and decrease in organic phase and at the different column (Inertsil ODS-3, column (250mmx4.6mm), 5 micron. There is no significant change in recovery of Polmacoxib. The \% RSD shown in table:8 negligible changes were observed during robust condition. So we can say that the developed method is robust.

Table 8: Robustness Data

\begin{tabular}{|l|l|l|}
\hline Drug & Parameters & \% RSD \\
\hline \multirow{5}{*}{ Polmacoxib } & Wavelength minus & 0.002 \\
\cline { 2 - 3 } & Wavelength plus & 0.003 \\
\cline { 2 - 3 } & Flow minus & 0.003 \\
\cline { 2 - 3 } & Flow plus & 0.0002 \\
\cline { 2 - 3 } & Organic phase ration change & 0.001 \\
\cline { 2 - 3 } & Column Change & 0.002 \\
\cline { 2 - 3 } & Temperature minus & 0.005 \\
\cline { 2 - 3 } & Temperature plus & 0.004 \\
\hline
\end{tabular}

\section{RESULT AND DISCUSSION}

After a number of trials with different, organic phase were tested but the adequate separation of Polmacoxib was found in Acetonitrile: Water (in Isocratic mode). The best results were obtained with flow rate programming of selected mobile phase for the purpose of rapid analysis. Mobile phase was started at a flow rate of $1.0 \mathrm{ml} / \mathrm{min}$ which was continued for $1.0 \mathrm{~min}$ to $10.00 \mathrm{~min}$.

The validation of the developed and the optimized RP-HPLC method was carried out with respect to the parameters such as specificity, linearity, accuracy, precision, limit of quantification (LOQ) and limit of detection (LOD) in the light of internationally accepted ICH guidelines. 


\section{CONCLUSION}

The HPLC method was successfully developed and validated on a Waters 2996 alliance for simultaneous determination of Polmacoxib. The method for simultaneous determination has not been reported before. This present method is novel for the determination of drug at a single wavelength, $10 \mu \mathrm{L}$ injection capacity and Phenomenex Luna C18 $5 \mu \mathrm{m}$ $4.6^{*} 150 \mathrm{~mm}$ column. It was the found that the method is sufficiently simple, rapid and sensitive as well as precise, accurate, linear, robust which compiles the ICH guidelines. The entire experimentation was proved that the developed HPLC method shows good resolution, linearity and RSD values (less than $2 \%$ ). Which indicate the method is suitable for the determination of Polmacoxib.

\section{ACKNOWLEDGEMENT:}

Authors are thankful to Indian Pharamcopoeial Commision for providing all necessary facilities for this work.

\section{REFERENCES}

1. Kim HT, Cha H, Hwang KY: Structural insight into the inhibition of carbonic anhydrase by the COX-2-selective inhibitor polmacoxib (CG100649). Biochem. Biophys. Res. Commun 2016; 1-6. https://doi.org/10.1016/j.bbrc.2016.07.114

2. Lee M, Yoo J, Kim JG, Kyung H S, Bin SI, Kang SB, Choi CH, Moon Y W, Kim YM, Han SB, In Y, Choi CH, Kim J, Lee BK, Cho S: A Randomized, Multicenter, Phase III Trial to Evaluate the Efficacy and Safety of Polmacoxib Compared with Celecoxib and Placebo for Patients with Osteoarthritis. Clin Orthop Surg 2017; 9:439457. https://doi.org/10.4055/cios.2017.9.4.439

3. Song IG, Jung KU, Kim HO, Kim H, Chun HK: An unusual case of colon perforation with multiple transmural ulcers after use of polmacoxib and everolimus in a metastatic breast cancer patient: A case report Ann Coloproctol 2020; 1-20.

4. Kyeon SY, Bang HC, Sohn YT: Solid state of a new COX-2 inhibitor CG100649 Characterization, dissolution, and transformation. J Therm Anal Calorim 2017; 1-8. https://doi.org/10.1007/s10973-017-6101-2

5. Prathapa B, Deyb A, Raoa GHS, Johnsona P, Arthanariswaran P: A Review - Importance of RP-HPLC in Analytical Method Development. IJNTPS 2013; 1-9.

6. Kumar DS, Kumar H: Importance of RP-HPLC in analytical method development: A Review. Int. J. Pharm. Sci. Res 2012; 3(12):4626-4633.

7. Patel S S, Ladva B J , Nayak B S, Patel S J, Mahida V M: Development of stability-indicating hplc method for simultaneous estimation of nebivolol hydrochloride and valsartan in tablet dosage form. World J Pharm Pharm Sci 2015; 4(6):662-670.

8. Ritihaas C S, Prakash B B: RP-HPLC Method Development and Validation for Simultaneous Estimation of Olmesartan Medoxomil and Hydrochlorothiazide. Int J Pharm Bio Sci 2015; 6(1):180-187.

9. Das S C, Roy S, Arefeen S, Rouf S S: Development and Validation of RP-HPLC Method for Quantitative Estimation of Vinpocetine in Pure and Pharmaceutical Dosage Forms. Chromatogr. Res. Int 2011; 1-7. https://doi.org/10.4061/2011/801656

10. N Itagimatha, D H Manjunatha: RP-HPLC-UV method development and validation for simultaneous determination of terbutaline sulphate, ambroxol $\mathrm{HCl}$ and guaifenesin in pure and dosage forms. Ann Pharm F 2019 Jul; 77(4):295-301. https://doi.org/10.1016/j.pharma.2019.02.004

11. Subramanian V B, Katari N K, Dongala T, Jonnalagadda S B: Stability-indicating RP-HPLC method development and validation for determination of nine impurities in apixaban tablet dosage forms. Robustness study by quality by design approach" "Biomed Chromatogr. 2020 Jan; 34(1):e4719. https://doi.org/10.1002/bmc.4719

12. Singh O, Kumar R, Kulkarni O, Reddanna P, Polamarasettyparoy: Understanding the Dual Inhibition of COX-2 and Carbonic Anhydrase-II by Celecoxib and CG100649 Using Density Functional. Theory Calculations and other Molecular Modelling Approaches Protein \& Peptide Letters. 2015; (10):903-912. https://doi.org/10.2174/0929866522666150622102131

13. Tripathi, K.D. Essentials of Medical Pharmacology, 6th ed. Jaypee Brothers Medical Publishers. 2008. P. 248-249. https://doi.org/10.5005/jp/books/10282

14. Indian Pharmacopoeia, The Indian Pharmacopoeia Commission, Ghaziabad.

15. ICH Q2B, Validation of Analytical Procedures: Methodology. 1997.

16. International Conference on Harmonization (ICH) Topic Q2A Validation of Analytical Procedures, Methodology, CPMP/ICH/281, (1995).

17. Sethi, P D, High Performance Liquid Chromatography, 1st ed. CBS Publishers and Distributors. 2001. P. 3-16.

18. Snyder,L R, Glajch J L, Kirkland J J, Practical HPLC Method Development, 2nd ed. John Wiley \& Sons, Inc, A Wileyinterscience Publication, USA, 1997. P. 2-9. https://doi.org/10.1002/9781118592014 